\title{
EFFECTS OF SURGICALLY IMPLANTED DUMMY TRANSMITTERS ON THE SOUTH AMERICAN CATFISH JUNDIÁ (Rhamdia quelen)
}

\author{
SCHULZ, U. H. \\ Universidade do Vale do Rio dos Sinos, Laboratorio de Ecologia de Peixes, C2, Av. UNISINOS, 950, \\ CEP 93022-000, São Leopoldo, RS, Brazil \\ Correspondence to: Uwe H. Schulz, Universidade do Vale do Rio dos Sinos, Laboratório de Ecologia de Peixes, \\ C2, Av. UNISINOS, 950, CEP 93022-000, São Leopoldo, RS, e-mail: uwe@ bios.unisinos.br \\ Received May 10, 2002 - Accepted August 5, 2002 - Distributed May 31, 2003
}

(With 2 figures)

\begin{abstract}
High water temperatures and low water quality may negatively influence wound healing, growth and transmitter retention in radio-tagged fish of tropical and subtropical water bodies which in turn may hamper radio tracking studies. For a period of 90 days, we compared growth of an experimental group of ten Rhamdia quelen, which were submitted to intraperitoneal dummy transmitter implantation, with that of a control group. Additionally, wound healing and transmitter expulsion were observed in the experimental group. Water temperature varied between $24^{\circ} \mathrm{C}$ and $30^{\circ} \mathrm{C}$ during the study. Experimental group and control fish decreased in body weight during the investigation period, but the differences between the mean individual weight loss in both groups were not significant (Student $t$-test, $p=0.64$ ). Wound healing in experiment group fish was advanced after 14 days, while after 70 days eight out of ten incision wounds were closed and cicatrized. One fish had its dummy transmitter expulsed through the ventral body wall. After 90 days two more fish had the dummies expulsed, one through the ventral body wall and the other through the antenna exit. One experimental group fish died with visible signs of infection. The results encourage the use of surgically implanted radio transmitters for long-term tagging studies at high water temperatures.
\end{abstract}

Key words: Rhamdia quelen, transmitter implantation, transmitter expulsion, growth.

\section{RESUMO}

Efeitos da implantação cirúrgica de modelos de radiotransmissores em Jundiá (Rhamdia quelen)

A retenção de radiotransmissores implantados, a cicatrização e o crescimento em peixes podem ser influenciados negativamente pelas altas temperaturas e pela baixa qualidade da água. Altas temperaturas podem ser especificamente importantes em estudos de radiotelemetria em rios e lagos tropicais e subtropicais. Durante um período de 90 dias comparamos o crescimento de um grupo de dez Rhamdia quelen submetidos a implantação intraperitoneal de modelos de radiotransmissores com o de um grupo-controle. No grupo experimental observamos as cicatrizações das feridas e expulsões dos modelos. A temperatura da água variou entre $24^{\circ} \mathrm{C}$ e $30^{\circ} \mathrm{C}$ durante o estudo. Os peixes dos dois grupos perderam peso, porém as diferenças da média da perda individual entre pesos iniciais e finais não foram significativas (teste $t, p=0,64$ ). A cicatrização no grupo experimental foi avançada após 14 dias. Após 70 dias, oito das dez feridas estavam fechadas e cicatrizadas e um peixe havia expulsado o modelo através da parede ventral. Após 90 dias, mais dois peixes haviam expulsado o modelo através da parede ventral e pela saída da antena. Um jundiá do grupo experimental morreu com sinais visíveis de infecção. Os resultados indicam que a implantação de radiotransmissores pode ser recomendada como método viável para investigações radiotelemétricas de peixes em corpos d'água com temperaturas altas.

Palavras-chave: Rhamdia quelen, implantação, expulsão, radiotransmissores, crescimento. 


\section{INTRODUCTION}

Many aspects of the life cycles of long-distance migratory fish from Brazil are almost unknown. Identifying factors which trigger spawning behavior, describing spawning habitats and/or feeding areas, and investigating response behavior to water management of large Brazilian reservoirs are essential to the conservation of fish stocks. Conventional tagging provides only limited information about the time and distance travelled between fish release and recapture points. Radiotracking studies have become increasingly important in investigating fish behavior in Brazilian freshwater systems. Since most studies involve long-term tracking, surgical implantation of transmitters into the peritoneal cavity is the most adequate method (Tyus, 1988; Lucas, 1989).

Surgical implantation of transmitters may be affected by high water temperatures and low water quality, which may favor incision infections and, consequently, increase mortality (Knights \& Lasee, 1987). No information is presently available about the reaction of the South American catfish jundiá (Rhamdia quelen) to implanted radio transmitters. Experiments with other catfish species, however, revealed mechanisms of transintestinal transmitter expulsion, which may severely hamper tracking studies (Summerfeld \& Mosier, 1984; Baras \& Westerloppe, 1999).

The objective of our pilot study, which envisioned a larger radiotagging experiment, was to investigate wound healing, growth, and transmitterexpulsion in Rhamdia quelen under controlled conditions. The null hypothesis tested assumed that individual mean weight increase would be equal in dummy-transmitter tagged and control fish.

\section{MATERIAL AND METHODS}

Twenty jundiá were obtained from a commercial aquaculture facility. Ten fish were anesthetized (2-phenoxyethanol $350 \mathrm{mg} . \mathrm{L}^{-1}$ ) and subjected to surgical dummy-transmitter implantation in the peritoneal cavity, following the procedure given in Adams et al. (1998), with the antenna protruding from the body wall at about $1.5 \mathrm{~cm}$ posterior to the lateral incision. After pipetting 0.4 $\mathrm{ml}$ of a $100 \mathrm{mg} \cdot \mathrm{ml}^{-1}$ oxytetracycline solution to minimize infection risk, the dummy insertion incisions were closed with three stitches of nonabsor- bable monofilament suture (Ethicon Ethipoint SC20). The dummy transmitters, sealed in epoxy, were of the same size and weight (diameter $1.3 \mathrm{~cm}$, length $4.5 \mathrm{~cm}$, antenna length $30 \mathrm{~cm}$, weight $8 \mathrm{~g}$ ) as ATS standard (model 10-28) transmitters. They were equipped with original plastic-coated teflon ATS whip antennas. The dummy transmitter weight averaged $2.1 \%$ of the body weight of the fish.

The surgery was carried out in five to eight minutes. Ten other fish making up the control group were anesthetized and individually tagged without application of antibiotics (oxytetracycline). Each catfish was marked with an opercular strap tag (McFarlane et al., 1990) on the right pelvic fin and weighed at the beginning of the experiment.

Control and dummy tagged fish were maintained in mixed groups in four $500 \mathrm{~L}$ fiberglass tanks at a density of five fish per tank in continuous water flow at $3 \mathrm{~L} \cdot \mathrm{min}^{-1}$. The water, drawn from a 2.7 ha impoundment on the university campus, ranged in temperature between $24^{\circ} \mathrm{C}$ to $30^{\circ} \mathrm{C}$ during the experiment. In times of heavy rain the impoundment may receive unknown amounts of organic sewage from illegal septic tank outlet connections of to the rain drainage system. Fish were fed to about $2 \%$ of their total body weight once a day except on weekends. Both groups were measured and weighed at the beginning of the experiment and after 90 days. After 14 and 70 days all fish were photographed and checked for wound healing and expulsed transmitters.

\section{RESULTS}

After 14 days, the incisions of seven of ten fish had closed completely with no inflammation either of the wound or of the antenna exit. Initial signs of infection appeared in two fish at the incision and in one fish at the antenna exit. They had not yet completed the wound closure process. All fish, including the control group, displayed pelvic fin infections due to the strap tag. In some fish, fin rays were broken during the tagging procedure. After 70 days, incision wound healing was complete in eight fish and most of the sutures had been expelled. One jundiá, with an infected incision, had died. Another had its dummy already expulsed through the ventral body wall, and in a third this process was beginning (Fig. 1). The catfish with the inflamed antenna exit had begun to expel the dummy through it. Inflammation of pectoral fins due to strap tags probably caused the death of four control group fish in (Table 1). 
TABLE 1

Mean initial and final weights of experimental and control group.

\begin{tabular}{|c|c|c|c|c|c|c|c|}
\hline & $\begin{array}{c}\text { Initial } \\
\text { mean } \\
\text { weight } \\
(\mathbf{g})\end{array}$ & sd & $\begin{array}{c}\text { Final } \\
\text { mean } \\
\text { weight } \\
(\mathbf{g})\end{array}$ & sd & $\begin{array}{c}\text { Mean } \\
\text { increase } \\
(\mathbf{g})\end{array}$ & sd & $\begin{array}{c}\text { Mortality } \\
(\mathbf{n})\end{array}$ \\
\hline $\begin{array}{c}\text { Experimental } \\
\text { group }\end{array}$ & 385.0 & 46.7 & 376.1 & 47.2 & $-7.7^{*}$ & 16.6 & 1 \\
\hline Control group & 340.4 & 45.5 & 357.9 & 39.5 & $-2.9^{*}$ & 23.0 & 4 \\
\hline
\end{tabular}

* Differences not significant; sd = standard deviation.

The experiment ended after 90 days. Fish of both groups had lost weight, but the means of individual differences between initial and final weight of experimental and control fish were not significant (Student t-test, $\mathrm{p}=0.67$; Table 1). All incision wounds of experimental fish had healed, and almost all sutures expelled. Both fish which had initiated dummy expulsion after 70 days had completed it and begun the expulsion wound healing process. The third catfish, which had expelled the dummy after 70 days through the ventral body wall had the resulting wound closed and almost completely cicatrized (Fig. 2).

\section{DISCUSSION}

Individual strap tags which were fixed on the pelvic fins had more negative consequences than the dummy transmitters. All fish of both groups showed inflammations, mostly because of broken fin rays. Probably these inflammations combined with poor water quality were responsible for the general weight decrease in the experimental and control groups. But even under these adverse circumstances the healing of dummy transmitter insertion wounds was fast.

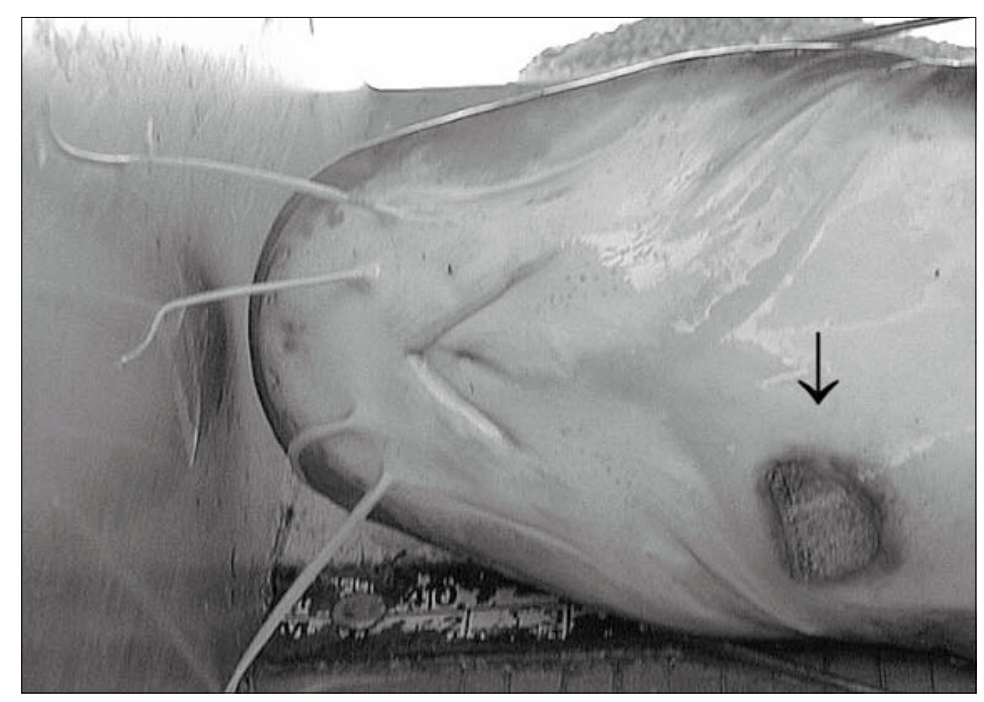

Fig. 1 - Transmitter expulsion $(\downarrow)$ after 70 days. 


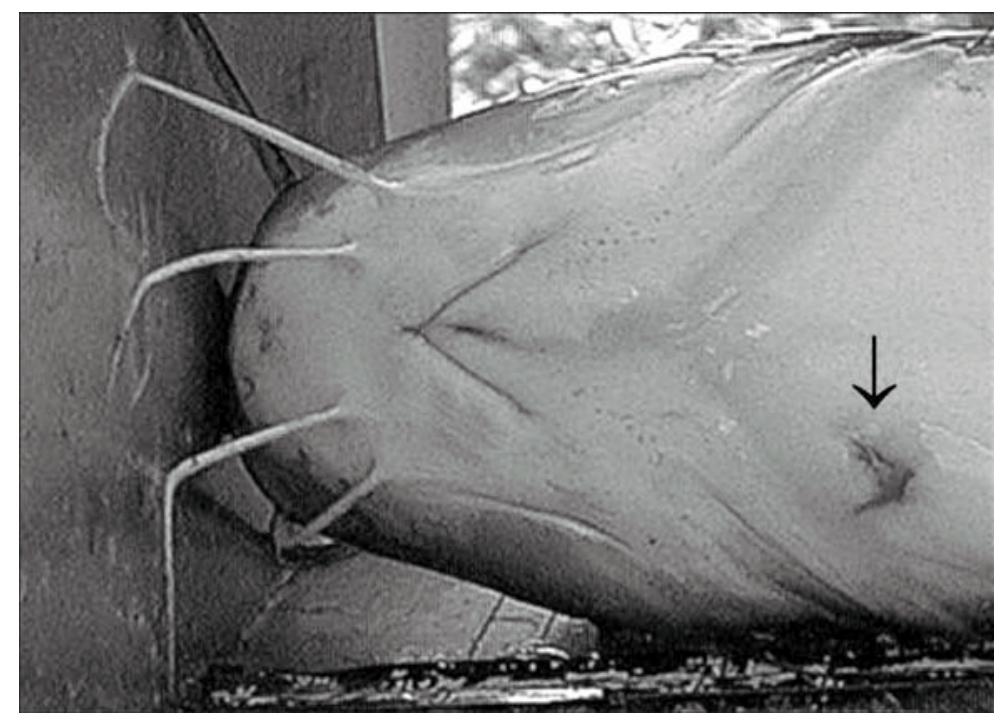

Fig. 2 - Expulsion wound $(\downarrow)$ cicatrized after 90 days.

The $10 \%$ mortality rate of the experimental group fish was equal to that shown by Knights \& Lasee (1987) in testing the effects of dummy transmitters on bluegills (Lepomis macrochirus).

Chisholm \& Hubert (1985) tagged 22 rainbow trout (Oncorhynchus mykiss) with dummy transmitters. Thirteen of these fish expelled the dummies from the body cavity within 47 to 175 days after surgery. The mechanism responsible for expulsion appeared to be encapsulation by the intestine and passage through the anus. Summerfeld \& Mosier (1984) described the same mechanism for American channel catfish Ictalurus punctatus, and Baras \& Westerloppe (1999) for the African catfish Heterobranchus longifilis. Transmitter expulsion in Rhamdia quelen did not occur via intestine-anus, but through the body wall in all three cases. All fish closed expulsion wounds quickly and displayed no further side effects.

Considering the adverse conditions of tankheld fish, the results suggest that intraperitoneal surgical transmitter implantation in Rhamdia quelen is possible. Side effects are not expected to be greater than those of radio-tagged fish of temperate climates. Finally, transmitter expulsion via the body wall may somewhat hamper radio tracking after 70 to 90 days.

\section{REFERENCES}

ADAMS, N. S., RONDORF, D. W., EVANS, S. D., KELLY, J. E. \& PERRY, R. W., 1998, Effects of surgically and gastrically implanted radio transmitters on swimming performance and predator avoidance of juvenile chinook salmon (Oncorhynchus tshawytscha). Can. J. Fish. Aquat. Sci., 55: 781-787.

BARAS, E. \& WESTERLOPPE, L., 1999, Transintestinal expulsion of surgically implanted tags by African catfish Heterobranchus longifilis of variable size and age. Trans. Am. Fish. Soc., 128: 737-746.

CHISHOLM, I. M. \& HUBERT, W. A., 1985, Expulsion of dummy transmitters by rainbow trout. Trans. Am. Fish. Soc., 114: 766-767.

KNIGHTS, B. C. \& LASEE, B. A., 1987, Effects of implanted transmitters on adult bluegills at two temperatures. Trans. Am. Fish. Soc., 125: 440-449.

LUCAS, M. C., 1989, Effects of implanted dummy transmitters on mortality, growth and tissue reaction in rainbow trout, Salmo gairdneri Richardson. J. Fish Biol., 35: 577-587.

McFARLANE, G. A., WYDOSKY, R. S. \& PRINCE, E. D., 1990, Historical review of the development of external tags and marks. Am. Fish. Soc. Symp., 7: 127-133.

SUMMERFELD, R. C. \& MOSIER, D., 1984, Transintestinal expulsion of surgically implanted dummy transmitters by channel catfish. Trans. Am. Fish. Soc., 113: 760-766.

TYUS, H. M., 1988, Long-term retention of implanted transmitters in Colorado squawfish and razorback sucker. N. Am. J. Fish. Manage, 8: 264-267. 